University of Nebraska - Lincoln

DigitalCommons@University of Nebraska - Lincoln

Faculty Publications, Department of Psychology

Psychology, Department of

2008

Crisis, What Crisis? Perception and Reality in Civil Justice

Brian H. Bornstein

University of Nebraska-Lincoln, bbornstein2@unl.edu

Timothy R. Robicheaux

Follow this and additional works at: https://digitalcommons.unl.edu/psychfacpub

Part of the Psychiatry and Psychology Commons

Bornstein, Brian H. and Robicheaux, Timothy R., "Crisis, What Crisis? Perception and Reality in Civil Justice" (2008). Faculty Publications, Department of Psychology. 344.

https://digitalcommons.unl.edu/psychfacpub/344

This Article is brought to you for free and open access by the Psychology, Department of at DigitalCommons@University of Nebraska - Lincoln. It has been accepted for inclusion in Faculty Publications, Department of Psychology by an authorized administrator of DigitalCommons@University of Nebraska - Lincoln. 


\title{
Crisis, What Crisis? Perception and Reality in Civil Justice
}

\author{
Brian H. Bornstein and Timothy R. Robicheaux
}

\begin{abstract}
"Excessive litigation has created a crisis in America," according to an article on the Alexandria, Virginia-based Center for Individual Freedom's website (Marcus, 2004).

This article was the first of 63,100 links retrieved in a February 16, 2007, Google.com search for the words "litigation crisis," and a search for the word "tort reform" on the same day returned over a million results. Not every linked article was as bold about the current "litigation crisis" in the United States, and not every linked article promoted a need for tort reform, but the search demonstrates the current salience of these issues in the United States.

There is clearly a perception that the civil justice system is, if not broken, in a serious state of disrepair (for reviews, see Greene \& Bornstein, 2003; Hans, 2006; Litan, 1993; Litan \& Winston, 1988; Vidmar \& Hans, in press); and although the jury is not painted as the sole culprit, it is portrayed as a leading one. The purpose of this introductory chapter is to provide an overview of some of the rhetoric about the civil jury system. As this chapter and the remainder of this book make clear, some of the rhetoric has a kernel of truth, but some of it is based on unvalidated assumptions and sensationalized sound-bytes that lack empirical justification.
\end{abstract}

\section{Perceptions of the Jury: Diametrically Opposed Views}

Much of the debate surrounding the civil justice system involves debates over the value and importance of civil juries in the United States. Two diametrically opposed views seem to exist concerning juries. One perspective is the "cup half-empty" view of juries. According to this perspective, held by many politicians, legislators, and professional/advocacy groups and fueled

Published in B. H. Bornstein et al. (eds.), Civil Juries and Civil Justice. (New York: Springer, 2008), pp. 1-19. Copyright (C) Springer 2008. Used by permission.

Correspondence-B. H. Bornstein, Department of Psychology, 328 Burnett Hall, University of Nebraska-Lincoln, Lincoln, NE 68588-0308, email bbornstein2@unl.edu 
by media coverage, juries are incompetent, illogical, and irrational (for reviews, see Galanter, 1998; MacCoun, 2006; Marder, 2003, 2005; Robbennolt \& Studebaker, 2003). While this perspective partly reflects sensationalism and the media's pandering to the public's seemingly endless appetite for stories of absurd, outrageous, and extreme lawsuits, it also partly reflects the operation of natural cognitive processes (e.g., the tendency for more salient, vivid information to capture the imagination and stand out in memory; see MacCoun, 2006, discussed below). The "cup half-empty" perspective has a symbiotic relationship with the tort reform and litigation crisis movements.

The opposing view, held by most (but certainly not all) social science researchers, is the "glass half-full" perspective. Those who hold this view agree that there is room for improvement in the United States' civil justice system, but that the errors are systematic and scientifically explainable. Unfortunately, these research findings often have little impact outside of academic circles.

However divergent these views may seem, there are reasons why people may subscribe to either perspective. Claims about the shortcomings of juries often result from ignorance, misrepresentation, or misunderstanding of the available data. Neither policymakers nor the media tend to be well trained in empirical methodology and statistical interpretation. On the other hand, those who do understand the methodology and interpretations - namely, the social scientists - are often poor at "selling" their research. Even when social scientists do disseminate and publicize their findings, empirical research on legal questions has significant limitations (e.g., questions about external and ecological validity, studies with conflicting results, etc.; see the chapter by Vidmar, this volume).

Reconciliation of these divergent viewpoints, if possible at all, will not happen overnight. Corporate profits, individual earnings (e.g., malpractice insurance and contingency fees), and well-heeled political lobbies provide financial hurdles to a successful reconciliation. Despite the uphill battle that social scientists are likely to face, there are reasons for optimism. The public, despite legislative and media complaints, does not exhibit a consistent proplaintiff bias but appears, rather, to have a surprisingly balanced perspective of the civil justice system (Feigenson, 2000; Hans; 2000). In addition, judges have an overwhelmingly positive view of the jury system (Galanter, 1990; Sentell, 1991), and there is a relatively low rate of judge and jury disagreement (Eisenberg et al., 2005; Kalven \& Zeisel, 1966; Sentell, 1991). Longitudinal trends in the civil justice system also show little cause for alarm: There are fewer jury trials today than in the past (evidence against a supposed "litigation crisis"; see Galanter, 2004), with little-to-no increase in award sizes (e.g., Seabury, Pace, \& Reville, 2004). By calling attention to data demonstrating juries as logical, rational, and competent, reform efforts can lead to the adoption of sound, empirically backed policies focusing on what really is broken, or performing at a sub-optimal level, and not on unfounded generalizations. 


\section{Torts Aren't Always Sweet: The Tort Reform Agenda}

Torts are not criminal offenses, and they are distinct from other non-criminal disputes such as contracts and property civil actions. Tort actions are between a plaintiff and a defendant; the goal is to determine liability (roughly speaking, a legal term for non-criminal culpability, or responsibility), not guilt; and the remedies in tort cases are usually monetary. In 2002, approximately $20 \%$ of civil trials in the United States were tort trials, which made tort cases more common than contract cases $(\sim 18 \%)$ but less common than prisoner petitions ( $30 \%$ ) (Galanter, 2004). Additionally, the proportion of tort cases, and of all civil cases, is decreasing over time (Galanter, 2004). Even though tort cases make up only a fraction of United States civil trials, legislatures, politicians and professional groups (i.e., those most likely to oppose juries) devote a great amount of time and energy to reforming tort law.

The largest and most visible tort reform lobbying group in the United States is the American Tort Reform Association (ATRA). ${ }^{1}$ ATRA, co-founded in 1986 by the American Medical Association and the Council of Engineering Companies, is "the only organization exclusively dedicated to repairing our civil justice system." Today, ATRA is "a nationwide network of state-based liability reform coalitions backed by 135,000 grassroots supporters." 2

ATRA's principal goals are highly laudable. The nonpartisan group works "to bring greater fairness, predictability and efficiency to America's civil justice system." ATRA compiles data on reforms to the tort systems in all state and federal courts. For instance, ATRA notes that in 2003 Texas placed a $\$ 250,000$ cap on noneconomic damages in medical malpractice cases and provided that defendants are no longer required to post a bond to appeal a punitive damages decision. A 2004 bill in Mississippi limited the liability of a seller of goods in a product liability case. Medical malpractice reform and product liability reform are frequent causes of ATRA, which is understandable considering that these are the types of cases most likely to affect the cofounding members (i.e., physicians and product manufacturers).

Many proponents of tort reform argue that the civil justice system in the United States is simply out of control, and that reform is the only sensible choice. According to ATRA, the United States spends $\$ 246$ billion on the civil

1. ATRA is by no means the only organization promoting "tort reform." Many professional organizations and individuals also promote reform of the tort system. We focus here on ATRA because the organization is highly visible, its website provides a wealth of useful information, and it clearly articulates the most common themes espoused by the tort reform movement.

2. The quotation is from ATRA's "About Us" page, retrieved on April 2, 2007, from http://www.atra.org/about/. Much of the information in the remainder of this section comes from multiple pages on the ATRA website. For brevity, we only cite the full web address for ATRA's "About Us" page, except for direct quotes. Readers are referred to the website for further information. 
justice system, making it the most expensive civil justice system in the world. How this dollar figure was calculated remains unclear; yet whether or not the statement controls for other variables in the calculation (e.g., population size), it is certainly plausible. It is also likely true of the United States' justice system as a whole, especially the criminal justice system. ${ }^{3}$

Assuming that tort reform advocates are correct and that the system is truly "out of control," who is to blame for this fact? ATRA blames both lawyers and the media. The million-plus lawyers in the United States (Galanter, 2004) are partially to blame for the out of control system, according to ATRA. As the number of lawyers per capita has more than doubled in the last 35 years (Galanter, 2004), personal injury lawyers are forced to "target certain professions, industries, and individual companies as profit centers." 4 Tort reform advocates blame lawyers for luring clients, some of whom have never suffered an actual injury, with promises of large awards. In addition, the lawyers "effectively tap the media to rally sentiments for multi-million dollar punitive damage awards." ${ }^{5}$

To achieve tort reform, ATRA lists several issues that they support:

- Health care liability reform

- Class action reform

- Promotion of jury service

- Abolition of the rule of joint and several liability

- Abolition of the collateral source rule

- Limits on punitive damages

- Limits on noneconomic damages

- Product liability reform

- Appeal bond reform

- Sound science in the courtroom

- Stopping regulation through litigation ${ }^{6}$

Most Americans would probably agree that many of these goals are socially desirable. For instance, the right to a trial by jury is a right that all Americans should appreciate, and promotion of jury service is quite desirable, for a number of reasons (Boatright, 2001; Diamond \& Bina, 2004). Social scientists who study legal issues would all agree with the need for sound science in the courtroom (e.g., Faigman, 1999; Monahan \& Walker, 2005; Faigman, Kaye, Saks, \& Sanders, 2002). On the other hand, while there are clear

3. Of course, an expensive system is not necessarily an out-of-control system. One could argue that "you get what you pay for," that significant amounts of money must be spent to achieve justice, and that inefficiencies are inevitable in any large bureaucracy. Nonetheless, there is always room for improvement.

4. ATRA's "About Us" page. Retrieved April 2, 2007, from http://www.atra. org/about/

5. Id.

6. Id. 
benefits to making the class action system more efficient, certain elements of class action reform could exclude some plaintiffs with legitimate causes of action. Also, limiting punitive or noneconomic damages serves defendants but could produce inadequate compensation to plaintiffs (Petrucelli $v$. Wisconsin Patients Compensation Fund, 2005; Sharkey, 2005) or inadequate punishment and deterrence to defendants and others (Galanter \& Luban, 1993; Sharkey, this volume).

\section{Tort Reform: The Efforts, the Consequences, and Jury Blame}

Jury trials are one vehicle for obtaining civil justice, but they are not the only vehicle. Some plaintiffs may obtain civil justice through mediation, arbitration, restorative justice schemes, or other means. However, many people seem to fear juries as irrational entities. Such "juryphobia" draws attention away from larger problems, such as medical and product errors, that professional organizations must address (Marder, 2005; see also chapters by Landsman and Miller, this volume). Most examples from ATRA's agenda are broad tort reforms that do not specifically target the jury. Some proposals implicate the jury without specifically targeting it, such as caps on damage awards (i.e., this particular reform is motivated at least partially by the perception that jury awards are excessive and irrational).

However, the "promotion of jury service" is one of ATRA's specific goals, suggesting a need for actual jury reform. Discussions of tort reform lay much of the blame for our allegedly dysfunctional civil justice system at the feet of juries, and the examples that the tort reform movement invariably trots out to demonstrate the need for reform (e.g., the McDonald's hot coffee case) center on juries. The "common wisdom" surrounding many of these purportedly outlandish and outrageous cases, such as the McDonald's coffee case, is often distorted or inaccurate (see, e.g., Galanter, 1998; Vidmar \& Hans, in press; we discuss several of these cases below).

Moreover, ATRA identifies several jurisdictions as "judicial hellholes," which are "places that have a disproportionately harmful impact on civil litigation. Litigation tourists, guided by their personal injury lawyers seek out these places because they know they will produce a positive outcome. ${ }^{\prime 7}$ One of the most salient cases of 2006 occurred in an area of Texas, the Rio Grande Valley and Gulf Coast area, named by ATRA as a judicial hellhole in both 2005 and in 2006. On April 21, 2006 a jury awarded a plaintiff \$32 million (capped at $\$ 7.75$ million) against Merck \& Company because a 71-year-old family member died after taking the pain reliever Vioxx (CNN Wire, 2006). While ATRA refers to this locale as "an area where extremely weak evidence can net multimillion dollar awards," and where "jurors have relationships

7. ATRA's Judicial Hellhole's page; retrieved on April 2, 2007, from http://www.atra. org/reports/hellholes/2005/ 
with the litigants in their cases, ${ }^{\prime 8}$ the jury in this case arguably showed a fair amount of restraint, considering that the plaintiffs requested over a billion dollars. Interestingly, jurors appear to have shown restraint in several cases against Merck over Vioxx, as the company has won seven Vioxx cases and lost only four cases as of December of 2006 (Vioxx Trial Scorecard, 2006).

West Virginia, South Florida, and three counties in Illinois also hold the dishonor of "judicial hellholes," but ATRA also identifies "points of light." These points of lights are places where voters, trial courts, or the legislature have instituted measures to reform the civil justice system. One "point of light" in 2006 was the Florida legislature, which limited class action lawsuits to plaintiffs from Florida (with some exceptions) and made it easier to appeal civil judgments.

While certain areas may be notorious for being overly plaintiff-friendly, ATRA also points out that some lawsuits are absolutely "looney." These cases are meant to illustrate how the justice system has spun out of control. For instance, a couple sued American Airlines because they did not have enough legroom, a student sued his school over summer homework, and a viewer of NBC's Fear Factor sued NBC for \$2.5 million claiming nausea caused from a rat-eating episode of the show caused him to run into a door (ATRA, 2006). To add to the outrage over such lawsuits, ATRA mentions two "Good Samaritan" teenagers who were sued after surprising neighbors with cookies (by ringing the doorbell and running away), which allegedly caused one neighbor to have a panic attack.

Perhaps the most famous example of an "outrageous" lawsuit that has become the stuff of legend is the McDonald's coffee spill case (Galanter, 1998). A woman sued McDonald's after she spilled hot coffee on her lap and suffered third degree burns on her groin and leg, necessitating skin grafts. McDonald's kept its coffee 20 degrees hotter than the industry standard, and this was one of approximately 700 previous claims concerning coffee burns. The woman asked for $\$ 11,000$ to pay for her medical bills; McDonald's countered with an offer of $\$ 800$, so she sued. The media reports discussed the large ( $\$ 2.7$ million) punitive damage award against McDonald's, but the award was reduced to $\$ 480,000$ (Galanter, 1998). Other salient cases include the Firestone tire and tobacco litigation, and most recently lawsuits against Merck over the drug Vioxx.

The ATRA is not the only professional organization to cite frivolous cases to further its cause, and it remains unclear how such suits demonstrate a broken system. They do demonstrate how partisan groups naturally are selective in adducing evidence to support a particular agenda. The "looney lawsuit" headlines do not indicate, for example, that the couple who sued American Airlines did so only after the airline advertised more legroom on their flights; or that a judge threw out the Fear Factor suit in March of 2005, and warned the (pro-se) plaintiff not to appeal the decision in the "frivolous" lawsuit (As-

8. Id. 
sociated Press, 2005). If anything, one could argue that these cases illustrate a justice system gone right. Cases that seem groundless at first blush can turn out, on closer inspection, to have some degree of legitimacy, and frivolous cases usually are dismissed. ${ }^{9}$

\section{The American Medical Association and Medical Malpractice Reform}

Other groups, in addition to the American Tort Reform Association, present their own records of a justice system gone bad. Physicians in at least twelve states have rallied against rising malpractice insurance rates by arguing for a need for tort reform (Denicola, n.d.). However, it is not at all clear that malpractice settlements are the primary determinant of malpractice premiums; other factors, such as market forces and increased attention to medical errors, play large roles as well (see, e.g., Black, Silver, Hyman, \& Sage, 2005; Greve, 2002). The American Medical Association (AMA) has a color-coded map that purports to demonstrate states in a "medical crisis" (see Figure 1). ${ }^{10}$ According to the map, there are seventeen states currently in "crisis," where the AMA warns that patients will lose access to "high-risk" medical procedures and medical specialists (AMA Crisis Map, n.d.). The AMA vigorously promotes medical malpractice reform.

Because of the crisis warnings, most states have enacted some form of medical malpractice reform along with their other tort reform measures (Halton \& McCann, 2004). The effectiveness of these reforms remains unclear, specifically in the medical "crisis" area. The Government Accounting Office surveyed five states with potential problems in medical care access. Rather than reflecting a malpractice crisis, shortages in emergency surgery and newborn delivery were in rural areas where "providers identified other long-standing factors that affect the availability of service" (Congressional Budget Office (CBO), 2004). The GAO could not substantiate reductions in physicians, and they found no widespread lack of access to medical care (CBO, 2004).

Is the focus on the civil justice system and out-of-control juries warranted as an explanation for rising malpractice insurance premiums? Recent data suggest not. In 2003, the Missouri Department of Insurance released a statement reporting that medical malpractice claims both filed and paid in 2003 fell to all-

9. Many states have, in recent years, cracked down on frivolous lawsuits by increasing penalties for litigants and lawyers who file them (e.g., http://www.usatoday.com/ news/nation/2005-08-16-lawsuit-penalty_x.htm). This trend is one of the clear successes of the tort reform movement.

10. The AMA updates the map regularly. Figure 1 was current as of May 16, 2007: for current status, see http://www.ama-assn.org/ama/noindex/category/1187.html. 


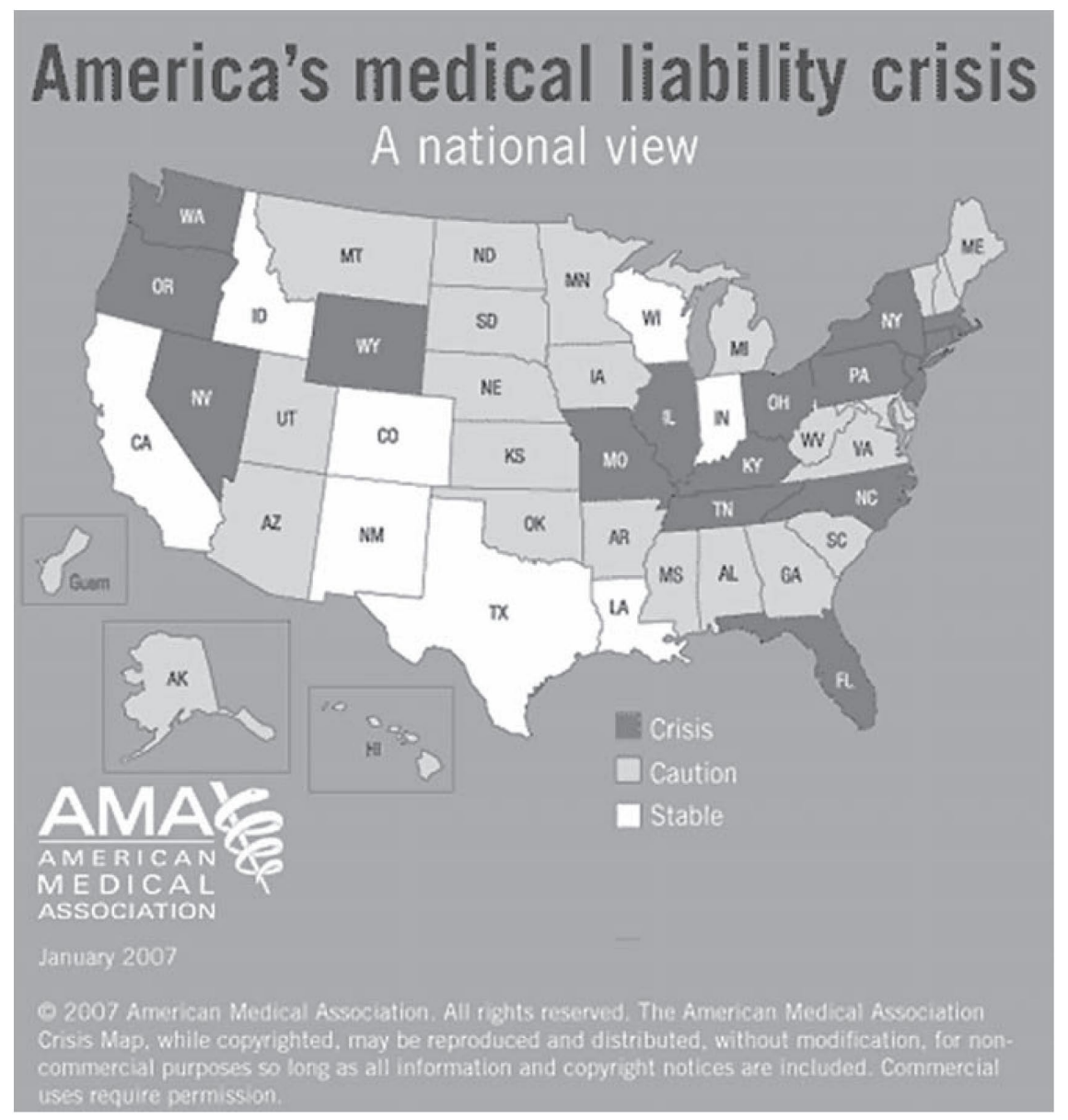

Figure 1. AMA crisis map

time lows (VandeWater, 2004), while medical malpractice companies increased premiums (Americans for Insurance Reform, 2004). A newspaper in New Jersey reported that medical malpractice payouts fell 21\% from 2001 to 2003, yet malpractice premiums increased over the same time-period (Herbert, 2004) ${ }^{11}$ In perhaps the most comprehensive study of medical malpractice claims outcomes to date, Black et al. (2005) analyzed closed claims in Texas from 1988 to 2002. They found that, controlling for population growth, the number of paid claims did not increase (and actually decreased for claims less than \$25,000); payouts per large paid claim $(\$ 25,000)$ increased trivially, no more than $0.5 \%$

11. Interestingly, the American Medical Association is not part of the Americans for Insurance Reform Coalition (http://www.insurance-reform.org/list.html) and remains focused on tort reform instead. 
per year; and although jury awards did increase approximately $3 \%$ per year, the actual payouts in tried cases did not increase over time. ${ }^{12}$

\section{The Consequences of Reform}

If tort reform efforts are accurately pinpointing the cause of the problem (if, indeed, there is a problem), then one would expect to see benefits in states that have initiated tort reforms. According to ATRA, there have been increasing business investments and job growth since the passage of tort reform. The AMA recently dropped Texas from its list of states in crisis after Texas capped noneconomic damages. There is evidence that malpractice claims and insurance rates have, in fact, decreased recently in Texas; however, the decrease began before Texas approved the cap (Black et al., 2005). Others have reported an increase in the supply of physicians following the passage of medical malpractice reform laws (Kessler, Sage, \& Becker, 2005).

It is exceedingly difficult to document the effects of reform efforts. Numerous factors can explain pre-versus post-reform differences, mostly related to the simple passage of time (e.g., changes in demographic patterns or economic indicators), and cross-sectional comparisons of states with and without various reform measures suffer from similar problems. ${ }^{13}$ The claims by ATRA and the AMA seem to argue causality in the face of clearly correlational data. The price of oil has increased since Texas capped noneconomic damages, but it is unlikely that ATRA would blame tort reform efforts for this change. Systematic studies of the issues purport to find both positive change (e.g., lower awards, fewer claims) and no changes at all, depending on the type of tort reform under investigation (see, e.g., Waters, Budetti, Claxton, \& Lundy, 2007).

In an attempt to overcome the difficulties inherent in analyzing the effects of reforms, some researchers have turned to conducting controlled experimental studies. An experimental approach allows for a systematic exploration of mock jury awards in cases where, for example, punitive damage awards are or are not capped (e.g., Greene, Coon, \& Bornstein, 2001; Robbennolt \& Studebaker, 1999; see generally Greene \& Bornstein, 2003). Although this approach to doing psycholegal research is associated with its own problems and limitations (see chapter by Vidmar, this volume), the research is generally consistent with archival analyses of actual jury verdicts and demonstrates inconsistent,

12. The figures reported here summarize across a number of analyses conducted by Black et al. (2005) using different data sets but capture the overall tenor of the results. The absence of an increase over time in actual payouts, despite the slight increase in jury award size, reflects the fact that most jury awards in medical malpractice cases receive post-verdict "haircuts" (Hyman, Black, Zeiler, Silver, \& Sage, 2007).

13. It is possible to control for many of these extraneous variables through sophisticated statistical techniques; see, e.g., the chapters by Sharkey and Eisenberg, Hans, and Wells, this volume. 
and sometimes unintended, effects of proposed legal reforms (e.g., capping damages; see Greene \& Bornstein, 2003; Sharkey, 2005).

Another problem the tort reform lobbyists face is the legality of their reforms. The Wisconsin Supreme Court recently held that a medical malpractice cap of $\$ 350,000$ on noneconomic damages was a violation of the plaintiff's equal protection right (Petrucelli v. Wisconsin Patients Compensation Fund, 2005). On a rational basis review (i.e., in applying a level of scrutiny that is relatively lax and generally favors the state), they held that the cap statute was not rationally related to a number of legitimate legislative objectives, such as compensating victims fairly, lowering medical malpractice insurance premiums, or lowering overall healthcare costs.

\section{Tempest in a Teapot?}

Although juries, or at least jury trials, get much of the attention from tort reform advocates, only a very small percentage of cases actually go to trial (e.g., Ostrom, Rottman, \& Goerdt, 1996), and going to trial does not guarantee that the case will be tried by a jury. Considering data on win-rates for different types of cases, the most controversial areas of law seem especially poor candidates for reform efforts. Overall, plaintiffs win cases about $50 \%$ of the time, but only $40 \%$ of the time in products liability cases and $30 \%$ of the time in medical malpractice cases (Ostrom et al., 1996). This means that for a contingency-paid lawyer to take such cases to court, he or she probably has a strong case, one worth a lot of money if the plaintiff wins, or both. Punitive damages, another area of focus by reform advocates, are awarded in only 3$5 \%$ of tort cases where the plaintiff wins (Eisenberg, Goerdt, Ostrom, Rottman, \& Wells, 1997, Eisenberg, LaFountain, Ostrom, Rottman, \& Wells, 2002; Ostrom et al., 1996; Rustad, 1998).

Nonetheless, juries do matter. Jury verdicts have an impact on both business (e.g., Garber \& Adams, 1998) and individual behaviors (e.g., Sloan, Reilly, \& Schenzler, 1995). Although variations in awards and verdicts make settlement decisions and negotiations more difficult (Galanter, 1990), these stages of the dispute resolution process nonetheless occur in "the jury's shadow" (Galanter, 2004; Metzloff, 1991). Despite their relative rarity and declining frequency, juries still try tort cases more often than other types of civil cases, such as contract or property disputes (Galanter, 1990, 2004). Thus, the jury system may, in some ways, be imperfect, inefficient, and expensive; yet trials, and especially jury trials, have a central and influential role in the American civil justice system whose importance it would be hard to overstate (Burns, 2003; Landsman, 2004). According to Burns (2003, p. 1319), "the American jury trial, as we have developed it, is one of the greatest achievements of American public culture." Many others - legal scholars, politicians, and laypeople-would undoubtedly agree with this sentiment. 
Tort reform proponents often argue that jury decisions have changed, and awards have increased, over time, causing the system to spiral out of control. Available data, however, do not demonstrate major changes in the last 40 years. Seabury and colleagues (2004) studied 40 years of civil jury verdicts (1960-1999) in San Francisco (California) and Cook (Illinois) Counties. The mean awards increased dramatically over this time, but median awards remained the same (Seabury et al., 2004). The mean awards, which are affected more by outliers, demonstrate the presence of more large awards in recent times. These large awards were still very rare. Moreover, most of the growth in awards could be credited to increased medical losses and not to pain and suffering claims. In other words, medical costs and awards increased together. Similar analyses of punitive damage awards indicate that they have not increased disproportionately over time either (Eisenberg, et al., 2002, 2006; this volume).

\section{Juries and the Goldilocks Conundrum}

A civil jury has a difficult job; like Goldilocks tasting the bears' porridge, jurors seek to award an amount that is not too high, is not too low, but is just right. A group of individuals lacking specialized knowledge must hear a case, determine complicated issues of liability (e.g., causation, negligence), and decide how much money is adequate to cover an injury. Not only must jurors worry about past medical bills and other costs, but they also must consider future losses and calculate a dollar amount for pain and suffering. Regarding future losses (e.g., medical bills, loss of work, etc.), jurors must weigh testimony that includes speculative projections and technical calculations. Even economic experts would have trouble making such calculations; yet throughout this process, jurors receive little guidance (Greene \& Bornstein, 2000).

Reform advocates accuse juries of offering excessive damage awards. This argument is interesting to social scientists because it encompasses many types of court cases, and it is directly relevant to several reform measures (e.g., caps). There is no clear definition of what makes a jury award "too large." Indeed, some data show that plaintiffs are more likely to be undercompensated than overcompensated. For example, Sloan and van Wert (1991) studied awards and medical costs for medical malpractice claimants. For birth-related injuries and emergency room injuries, plaintiffs received $57 \%$ and $80 \%$ of their estimated costs, respectively (Sloan \& van Wert, 1991; see also Sloan \& Hsieh, 1990). The disparity was greatest for plaintiffs who died due to their injuries.

As the law dictates, injury severity remains the single best predictor of compensatory damages (Bovbjerg, Sloan, Dor, \& Hsieh, 1991; Sharkey, 2005; Vidmar, 1998; Vidmar, Gross, \& Rose, 1998), and large pain and suffering awards may be justified. In many cases, for example, a limited pain and suffering award would be inadequate to compensate someone who faces de- 
cades of paralysis and disfigurement. ${ }^{14}$ Punitive damages also must be large enough to serve their purpose - to punish a defendant and deter others. A small punitive damage award probably would not dissuade or alter the behavior of a billion dollar company.

Despite overall trends, tort reform advocates often bring up "blockbuster" awards - that is, awards that seem abnormally high. For instance, Viscusi (2004; see also Hersch \& Viscusi, 2004) identified 64 punitive damage awards since 1985 that were greater than $\$ 100$ million. Sixty-one of the 64 cases were tried by a jury, which suggested to the authors that juries are excessive and irrational in awarding punitive damages. In considering these blockbuster cases, there are a number of important considerations: first, the sheer magnitude of the awards cannot indicate whether or not they are excessive (i.e., an extremely large award might be necessary to achieve punishment/deterrence, especially when the defendant's actions were unusually reprehensible or committed by a multinational conglomerate). Second, other analyses of punitive damage awards suggest, counter to the claim of Hersch and Viscusi, that punitive damage awards are predictable and systematic (e.g., Eisenberg et al., 2002, 2006; see Eisenberg et al., this volume, for such an analysis that incorporates the cases summarized by Hersch and Viscusi). Third, appeals courts later reduced many of these very high awards (Baldus, MacQueen, \& Woodworth, 1995; Vidmar, Gross, \& Rose, 1998) ${ }^{15}$ Fourth, these large awards may be salient, but in the course of almost 20 years, there were very few blockbuster punitive cases. Fifth, judges and juries tend to award punitive damages similarly (Eisenberg et al., 2002, 2006; Robbennolt, 2002, 2005).

Despite the occasional blockbuster award (e.g., a \$253.4 million award in a recent Vioxx trial, expected to be reduced to approximately $\$ 26$ million; see Hays \& Agovino, 2005; Vioxx Trial Scorecard, 2006), jury awards tend to be quite modest. For example, Ostrom et al. (1996) analyzed a large number of state court trials and obtained a median award of approximately $\$ 52,000$. Only $8 \%$ of cases were above $\$ 1$ million, although the rate of million dollar cases varied by case type (e.g., $17 \%$ of medical malpractice cases were above $\$ 1$ million). Although award size has increased for some types of cases (e.g., medical malpractice), much of the increase can be explained by increasing medical costs (Seabury et al., 2004; Vidmar, 1998; Vidmar et al., 1998); and awards in the most common kind of case-automobile negligence-have not increased over time (Seabury et al., 2004). Thus, the data seem to support a

14. It is for this reason that the Wisconsin Supreme Court struck down that state's pain-andsuffering damages cap in the Petrucelli case discussed above.

15. Other sources of post-verdict "haircuts," such as a post-verdict settlement for insurance policy limits, are a more common cause of award reduction than remittitur (Hyman et al., 2007). Note that, in and of itself, the post-verdict reduction of apparently excessive awards (by remittitur or any other reason) does not indicate that juries are behaving rationally; but it does indicate that the civil justice system on the whole is functioning more as it is meant to function. 
conclusion that juries are not out of control, and that blockbuster awards by "runaway juries" are the exception, not the norm.

\section{Tort Reform and the Media: Is the Tort Reform Movement Shooting Itself in the Foot?}

Despite the fact that most data support juror/jury rationality and a system not in crisis, tort reform advocates continue to believe that changes in the jury system are necessary. Why does belief in a civil justice crisis persist, and what does the public believe? One explanation is that blockbuster awards are prominent in the media (Bailis \& MacCoun, 1996; Robbennolt \& Studebaker, 2003). For example, MacCoun (2006, p. 541) argues that "media distortion may be parsimoniously explained by...skewed outcome distribution combined with human brains that [attend] selectively." In other words, people are especially attuned to, and interested in, abnormal or "outlier" data.

Bailis and MacCoun (1996) analyzed 246 articles on tort litigation from 1980 to 1990 in Time, Newsweek, Fortune, Forbes, and Business Week. A person could conclude, after reading these articles, that plaintiffs have higher winrates and receive more damages than actual data demonstrate, as articles overrepresented both issues. The magazines also overrepresented articles on controversial forms of litigation, such as products and medical liability cases. For instance, automobile cases comprise $60 \%$ of tort filings and $42 \%$ of tort trials, but only $2 \%$ of legal articles in the magazines concerned automobile negligence trials (Bailis \& MacCoun, 1996). Products liability cases, comprising $4 \%$ of trials, received $49 \%$ of the attention in the articles, and medical malpractice cases were overrepresented as well (7\% actual rate; $25 \%$ coverage rate) (Bailis \& MacCoun, 1996).

At least three of the magazines surveyed focus exclusively on business, so the emphasis on business-related cases is understandable. The casual reader, however, might utilize the media reports to form opinions of the state of the civil justice system as a whole, especially if journalists report on interesting cases without focusing on their representativeness (MacCoun, 2006). MacCoun also argues that human evolution leads the public to give higher weight to abnormal stimuli, and damage awards are skewed in such a way that the only abnormal stimuli will be on the unbounded, high side. MacCoun posits that journalists will seek cases with large awards, which are more common in products liability, medical malpractice, and class action cases, and are only possible if the plaintiff wins the case. Thus, it is understandable that journalists allow extreme cases to be overrepresented - that is, after all, what sells.

In support of this argument, MacCoun (2006) observes that journalists commonly report outliers in a number of different domains. In addition to abnormal jury awards, journalists report "world's oldest human" stories, 
lottery winnings, record temperatures, and swings in stock prices (MacCoun, 2006). It is likely that journalists' story choices have little, if anything, to do with a tort reform agenda. Instead, they cater to public demand, as the public processes information in a certain way. The media alone, without the efforts of a tort reform group, seemingly distort certain case types and outcomes in the same way that tort reformers focus on "judicial hellholes" and "looney lawsuits."

Ironically, the media and tort reform groups might unwittingly be fanning the flames that the tort reform effort is trying to extinguish. If people make judgments based on media information, then potential or actual plaintiffs should be more likely to file suits and less likely to settle than they would be otherwise, because they will expect high win-rates and large awards. Jurors, who are themselves members of the public, will also expect high awards to be "normal" and will reach verdicts accordingly. On the other side, potential defendants, such as inventors and producers, who follow media reports closely, should be too scared to produce things for fear of being sued; after all, if these reports are to be believed, blockbuster awards and high plaintiff win-rates are the norm. Thus, by bundling calls for reform with evidence of extreme verdicts, the tort reform movement may be shooting itself in the foot.

\section{The Pervasiveness of the Tort Reform Debate}

ATRA, and other like-minded organizations, keep tort reform issues at the center of legislative and public policy debates. For instance, the Vioxx litigation was co-opted by the tort reform movement almost immediately. Stories on tort reform are also common in the media. According to news archive searches on The New York Times and Los Angeles Times websites, "tort reform" is a somewhat common topic (mentioned approximately 35 times in 2005 by both papers; it is likely that these numbers are smaller than the actual values, given the probable existence of additional articles using different terminology). As shown in Figure 2, the frequency of tort reform articles is somewhat variable yet relatively steady over time. ${ }^{16}$

Tort reform also appears to be an important issue in popular culture, as evidenced by a search of Google.com for the phrase "tort reform." A search on February 18, 2007 yielded over a million links for the phrase "tort reform." Searching for " 'tort reform' bad" yielded about 539,000 links, while " 'tort reform' good" yielded about 845,000 . Of course, this is a crude search of the prevalence and opinions on the issue (e.g., a link may have said "It is bad not to have tort reform" or "It's a good thing tort reform efforts are being stifled"), but tort reform is obviously a prominent issue that is not going to go away any time soon.

16. We could not determine a reason for the spike in 1995. 


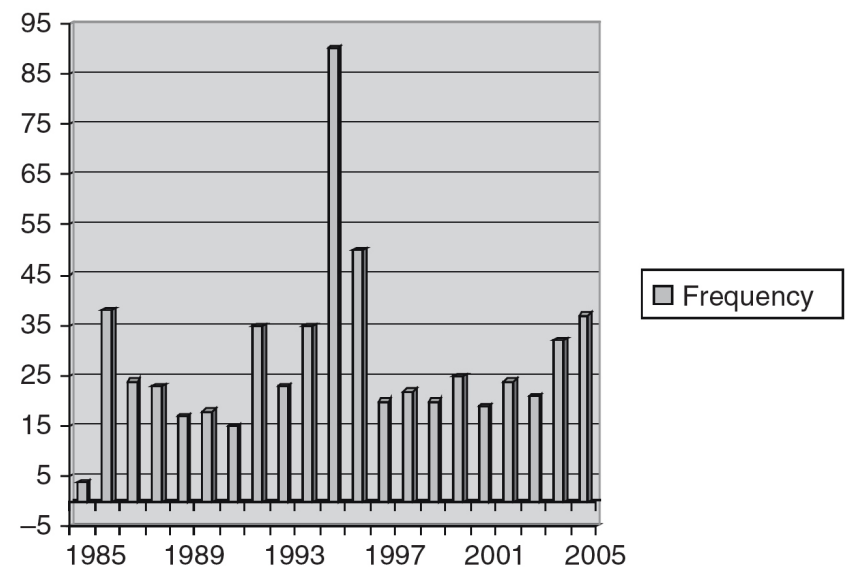

Figure 2. Frequency of phrase "tort reform" (based on web search of the L.A. Times archives)

\section{Recommendations: Where Do We Go From Here?}

The rhetoric of the tort reform and jury reform movements waxes and wanes, but it is likely here to stay. Reformist organizations, which often represent special interest and/or professional groups (e.g., physicians and product manufacturers), have invested large amounts of money into reform movements and have evidence that their efforts are protecting the interests of members. Some of this evidence is correct, some of it is merely correlational but taken to have causal implications, and some of it is erroneous. Unfortunately, it is unclear that all reform goals are socially desirable (e.g., caps on pain and suffering could potentially limit compensation to the most severely injured plaintiffs).

The blame may be misplaced (e.g., on juries instead of insurance companies), but tort reform advocates could benefit the civil justice system as a whole by focusing on less controversial reforms that are either absent from the agenda or less publicized. Several states have recently taken steps to help jurors to do their job properly by improving jury instructions, increasing juror compensation, and producing juror education/orientation videos with information relevant to rational decision-making (Greene \& Bornstein, 2000; Marder, 2006; Miller \& Bornstein, 2004). Legislatures and reform advocates could also benefit the system by allowing note-taking and question-asking during complicated trials (see, e.g., ForsterLee, Horowitz \& Bourgeois, 1994; Heuer \& Penrod, 1994; Mott, 2003).

One of the most difficult tasks for civil jurors is quantifying the exact amount of damages (Kalven, 1958; Greene \& Bornstein, 2000, 2003). In addition to simply clarifying the standard instructions, some reform measures advocate providing jurors with "benchmark" data from similar trials so that 
they have a frame of reference in deciding how much to award in damages (Bovbjerg, Sloan \& Blumstein, 1989; Dann, 2003). Although there are complexities in determining exactly which data to use for this purpose (Bovbjerg et al., 1989), there seems little doubt that having such information would make civil jury verdicts more equitable, in the sense of awarding similar amounts to similarly situated plaintiffs.

Most importantly, the tort reform movement demonstrates a heightened need for good jury research. Policy formulation in the absence of reliable data is empty and potentially harmful (Saks, 1989, 1992). Calls for reform are more data-driven than in the past, but data are still lacking or inconclusive on many questions relevant to juries. A valuable contribution of the chapters that follow is that their largely empirical approach can add to the kind of thoughtful, balanced discussion of the civil justice system that is essential to any debate about the merits and limitations of the American civil justice system.

\section{References}

American Medical Association Crisis Map. (n.d.). Retrieved on April 2, 2007 from: $\underline{\text { http:// }}$ www.ama-assn.org/ama/noindex/category/11871.html .

The American Tort Reform Association. "About Us" page. Retrieved on April 2, 2007 from: http://www. atra. org/about/. (Homepage: http://www. atra. org ).

Americans for Insurance Reform. (2004). Subject: Urgent action required by insurance commissioners to end price-gouging. Retrieved on April 2, 2007 from: http://www. centerjd. org/air/AIR Ins Comm 04. pdf.

Associated Press. (2005). Judge nixes viewer's “Fear Factor" lawsuit. Retrieved on April 2, 2007 from: http://www. foxnews. com/story/0,2933,150034,00. html .

Bailis, D. S., \& MacCoun, R. J. (1996). Estimating liability risks with the media as your guide: A content analysis of media coverage of tort litigation. Law and Human Behavior, 20, 419-429.

Baldus, D., MacQueen, J. C., \& Woodworth, G. (1995). Improving judicial oversight of jury damage assessments: A proposal for the comparative additur/remitittitur of awards for nonpecuniary harms and punitive damages. Iowa Law Review, 80, 1009-1267.

Black, B., Silver, C., Hyman, D. A., \& Sage, W. M. (2005). Stability, not crisis: Medical malpractice claim outcomes in Texas, 1988-2002. Journal of Empirical Legal Studies, 2, 207-259.

Boatright, R. G. (2001). Generational and age-based differences in attitudes towards jury service. Behavioral Sciences and the Law, 19, 285-304.

Bovbjerg, R. R., Sloan, F. A., \& Blumstein, J. F. (1989). Valuing life and limb in torts: Scheduling "pain and suffering. " Northwestern University Law Review, 83, 908-976.

Bovbjerg, R. R., Sloan, F. A., Dor, A., \& Hsieh, C. R. (1991). Juries and justice: Are malpractice and other personal injuries created equal? Law and Contemporary Problems, 54, 5-42.

Burns, R. P. (2003). A conservative perspective on the future of the American jury trial. Chicago-Kent Law Review, 78, 1319-1357.

Congressional Budget Office. (2004). Limiting tort liability for medical malpractice. Retrieved on April 2, 2007, from http://www. cbo. gov/showdoc. cfm?index $=4968$.

CNN Wire. (2006). Friday, April 26 (Merck found liable in latest Vioxx verdict). Retrieved on April 2, 2007, from http://www. cnn. com/2006/WORLD/europe/04/21/friday/ index. html. 
Dann, B. M. (2003). Jurors and the future of "tort reform. " Chicago-Kent Law Review, 78, 1127-1142.

Denicola, L. (n. d.). Physicians protest cost of malpractice insurance: Rising fees have doctors calling for legislative reforms. Retrieved on April 2, 2007 from http://nbs. gmnews. com/News/2002/1114/Front_Page/006. html.

Diamond, S. S., \& Bina, J. (2004). Puzzles about supply-side explanations for vanishing trials: A new look at fundamentals. Journal of Empirical Legal Studies, 1, 637-658.

Eisenberg, T., Goerdt, J., Ostrom, B., Rottman, D., \& Wells, M. T. (1997). The predictability of punitive damages. Journal of Legal Studies, 26, 623-660.

Eisenberg, T., LaFountain, N., Ostrom, B., Rottman, D., \& Wells, M. T. (2002). Judges, juries, and punitive damages: An empirical study. Cornell Law Review, 87, 743-780.

Eisenberg, T., Hannaford-Agor, P. L., Hans, V. P., Waters, N. L., Munsterman, G. T., Schwab, S. J., \& Wells, M. T. (2005). Judge-jury agreement in criminal cases: A partial replication of Kalven and Zeisel's The American Jury. Journal of Empirical Legal Studies, 2, 171-206.

Eisenberg, T., Hannaford-Agor, P. L., Heise, M., LaFountain, N., Munsterman, G. T., Ostrom, B., \& Wells, M. T. (2006). Juries, judges, and punitive damages: Empirical analyses using the civil justice survey of state courts 1992, 1996, and 2001 data. Journal of Empirical Legal Studies, 3, 263-295.

Faigman, D. L. (1999). Legal alchemy: The use and misuse of science in the law. New York: W. H. Freeman.

Faigman, D. L., Kaye, D. H., Saks, M. J., \& Sanders, J. (2002). Science in the law: Social and behavioral science issues. St. Paul, MN: West Group.

Feigenson, N. (2000). Legal blame: How jurors think and talk about accidents. Washington, DC: American Psychological Association.

ForsterLee, L., Horowitz, I. A., \& Bourgeois, M. (1994). Effects of notetaking on verdicts and evidence processing in a civil trial. Law and Human Behavior, 18, 567-578.

Galanter, M. (1990). The civil jury as regulator of the litigation process. University of Chicago Legal Forum, 201-271.

Galanter, M. (1998). An oil strike in hell: Contemporary legends about the civil justice system. Arizona Law Review, 40, 717-752.

Galanter, M. (2004). The vanishing trial: An examination of trials and related matters in federal and state courts. Journal of Empirical Legal Studies, 1, 459-570.

Galanter, M., \& Luban, D. (1993). Poetic justice: Punitive damages and legal pluralism. American University Law Review, 42, 1393-1463.

Garber, S., \& Adams, J. (1998). Product and stock market responses to automotive product liability verdicts. Brookings Papers on Economic Activity. Microeconomics, 1-44.

Greene, E., \& Bornstein, B. H. (2000). Precious little guidance: Jury instruction on damage awards. Psychology, Public Policy, and Law, 6, 743-768.

Greene, E., \& Bornstein, B. H. (2003). Determining damages: The psychology of jury awards. Washington, DC: American Psychological Association.

Greene, E., Coon, D., \& Bornstein, B. H. (2001). The effects of limiting punitive damage awards. Law and Human Behavior, 25, 217-234.

Greve Jr., P. A. (2002). Anticipating and controlling rising malpractice insurance costs. Healthcare Financial Management, 56, 50-55.

Halton, W., \& McCann, M. (2004). Distorting the law: Politics, media, and the litigation crisis. Chicago: University of Chicago Press.

Hans, V. P. (2000). Business on trial: The civil jury and corporate responsibility. New Haven, CT: Yale University Press. 
Hans, V. P. (Ed.) (2006). The jury system: Contemporary scholarship. Hampshire: Ashgate Publishing.

Hays, K., \& Agovino, T. (2005). Jury awards widow \$253.4 M in Vioxx Trial.

Retrievedon June 19, 2007, from http://www.breitbart.com/article. php?id=D8C362V00\&show article $=1$.

Herbert, B. (2004). Medical malpractice lawsuits: Do we have a crisis or insurance industry sham? Originally published in The New York Times (June 25, 2004). Retrieved on April 2, 2007, from http://reclaimdemocracy.org/articles 2004/malpractice crisis or sham. html.

Hersch, J., \& Viscusi, W. K. (2004). Punitive damages: How judges and juries perform. Journal of Legal Studies, 33, 1-35.

Heuer, L., \& Penrod, S. (1994). Juror notetaking and question asking during trials: A national field experiment. Law and Human Behavior, 18, 121-150.

Hyman, D. A., Black, B., Zeiler, K., Silver, C., \& Sage, W. M. (2007). Do defendants pay what juries award? Post-verdict haircuts in Texas medical malpractice cases, 19882003. Journal of Empirical Legal Studies, 4, 3-68.

Kalven, H. (1958). The jury, the law, and the personal injury damage award. Ohio State Law Journal, 19, 158-178.

Kalven, H., \& Zeisel, H. (1966). The American Jury. Boston: Little, Brown.

Kessler, D. P., Sage, W. M., \& Becker, D. J. (2005). Impact of malpractice reforms on the supply of physician services. Journal of the American Medical Association, 293, 2618-2625.

Landsman, S. (2004). So what? Possible implications of the vanishing trial phenomenon. Journal of Empirical Legal Studies, 1, 973-984.

Litan, R. E. (Ed.) (1993). Verdict: Assessing the civil jury system. Washington, DC: The Brookings Institution.

Litan, R. E., \& Winston, C. (Eds.) (1988). Liability: Perspectives and policy. Washington, DC: The Brookings Institution.

MacCoun, R. J. (2006). Media reporting of jury verdicts: Is the tail (of the distribution) wagging the dog? DePaul University Law Review, 55, 539-562.

Marcus, B. (2004). America's litigation crisis. Retrieved April 2, 2007, from Center for Individual Freedom Web site: http://www.cfif.org/htdocs/freedomline/current/guest commentary/american_litigation_crisis.htm .

Marder, N. (2003). Introduction to "The Jury at a crossroad: The American experience." Chicago-Kent Law Review, 78, 909-933.

Marder, N. (2005). The medical malpractice debate: The jury as scapegoat. Loyola of Los Angeles Law Review, 38, 1267-1296.

Marder, N. (2006). Bringing jury instructions into the twenty-first century. Notre Dame Law Review, 81, 449-511.

Metzloff, T. B. (1991). Resolving malpractice disputes: Imaging the jury's shadow. Law and Contemporary Problems, 54, 43-129.

Miller, M. K., \& Bornstein, B. H. (2004). Juror stress: Causes and interventions. Thurgood Marshall Law Review, 30, 237-269.

Monahan, J., \& Walker, L. (2005). Social Science in Law (6th ed.). New York: Foundation Press.

Mott, N. L. (2003). The current debate on juror questions: "To ask or not to ask, that is the question." Chicago-Kent Law Review, 78, 1099-1125.

Ostrom, B. J., Rottman, D. B., \& Goerdt, J. A. (1996). A step above anecdote: A profile of the civil jury in the 1990s. Judicature, 79, 233-241.

Petrucelli v. Wisconsin Patients Compensation Fund, 701 N. W. 2d 440 (Wisc. 2005). 
Robbennolt, J. K. (2002). Punitive damage decision making: The decisions of citizens and trial court judges. Law and Human Behavior, 26, 315-341.

Robbennolt, J. K. (2005). Evaluating juries by comparison to judges: A benchmark for judging? Florida State University Law Review, 32, 469-509.

Robbennolt, J. K., \& Studebaker, C. A. (1999). Anchoring in the courtroom: The effects of caps on punitive damages. Law and Human Behavior, 23, 353-373.

Robbennolt, J. K., \& Studebaker, C. A. (2003). News media reporting on civil litigation and its influence on civil justice decision making. Law and Human Behavior, 27, 5-27.

Rustad, M. L. (1998). Unraveling punitive damages: Current data and further inquiry. Wisconsin Law Review, 15-69.

Saks, M. J. (1989). Legal policy analysis and evaluation. American Psychologist, 44, 1110-1117.

Saks, M. J. (1992). Do we really know anything about the behavior of the tort litigation system - and why not? University of Pennsylvania Law Review, 140, 1147-1292.

Seabury, S. A., Pace, N. M., \& Reville, R. T. (2004). Forty years of civil jury verdicts. Journal of Empirical Legal Studies, 1, 1-25.

Sentell, R. P. (1991). The Georgia jury and negligence: The view from the bench. Georgia Law Review, 26, 85-178.

Sharkey, C. M. (2005). Unintended consequences of medical malpractice damages caps. New York University Law Review, 80, 391-512.

Sloan, F. A., \& Hsieh, C. R. (1990). Variability if medical malpractice payments: Is the compensation fair? Law and Society Review, 24, 997-1039.

Sloan, F. A., Reilly, B. A., \& Schenzler, C. (1995). Effects of tort liability and insurance on heavy drinking and driving and driving. Journal of Law and Economics, 38, 49-77.

Sloan, F. A., \& van Wert, S. S. (1991). Cost and compensation of injuries in medical malpractice. Law and Contemporary Problems, 54, 131-168.

VandeWater, J. (2004). Missouri insurance department says malpractice claims hit new lows in 2003. St. Louis Post-Dispatch (April 17, 2004). Retrieved on April 2, 2007, from http://www.accessmylibrary.com/coms2/summary_0286-7640872_ITM.

Vidmar, N. (1998). The performance of the American civil jury: An empirical perspective. Arizona Law Review, 40, 849-899.

Vidmar, N., Gross, F., \& Rose, M. (1998). Jury awards for medical malpractice and post-verdict adjustments of those awards. DePaul Law Review, 48, 265-299.

Vidmar, N., \& Hans, V. P. (in press). American juries: The verdict. New York: Prometheus Books.

Viscusi, W. K. (2004). The blockbuster punitive damages awards. Emory Law Journal, 53, 1405-1455.

Vioxx Trial Scorecard. (2006). Retrieved on April 2, 2007, from http:/ /www.virsci.com/ VioxxTrialScorecard.pdf.

Waters, T. M., Budetti, P. P., Claxton, G., \& Lundy J. P. (2007). Impact of state tort reforms on physician malpractice payments. Health Affairs, 26, 500-509. 